\title{
A Review of Critical Success Factors Which Drives the Performance of Micro, Small and Medium Enterprises
}

\author{
Isaac Mabhungu ${ }^{1} \&$ Breggie Van Der Poll ${ }^{2}$ \\ ${ }^{1}$ Department of Management Accounting, University of South Africa, South Africa; Bindura University of \\ Science Education, Zimbabwe \\ ${ }^{2}$ Unisa Graduate School of Business Leadership, South Africa \\ Corresponding author: Isaac Mabhungu, Department of Management Accounting, University of South Africa, \\ South Africa. E-mail: Isaac.mabhungu@gmail.com
}

Received: March 18, 2017

Accepted: April 30, 2017

Online Published: May 17, 2017

doi:10.5539/ijbm.v12n6p151

URL: https://doi.org/10.5539/ijbm.v12n6p151

\begin{abstract}
The survival of Micro, Small and Medium Enterprises (MSMEs) depends on their ability to effectively manage the factors that affect their performance. The study identifies through literature review, the various factors that may be critical to the success of MSMEs in the retail sector, and therefore enhance their survival. Identification of Critical Success Factors (CSFs) is important in that it may bring to the attention of MSMEs those CSFs which need to be focused on in order to operate in a profitable and sustainable manner. Owner/manager commitment, employee commitment, business planning, innovation, management of costs, customers, suppliers, information, revenue, competitors, sources of finance, enterprise's pool of resources and conformance to regulations were identified as some of the CSFs which influence the success and survival of MSMEs. The study is informed and guided by the stakeholder theory. The research lays a foundation for future study on performance measurement framework for MSMEs in the retail sector.
\end{abstract}

Keywords: critical success factor, msmes, performance, survival

\section{Introduction}

Micro, Small and Medium Enterprises play a pivotal role in the economic development of any country. Recent research highlights the importance of MSMEs in employment creation, poverty alleviation and economic development in both developed and developing economies (Asah, Fatoki \& Rungani, 2015; Isaga, Masurel \& Van Montfort, 2015; Massa, Farneti \& Scappini, 2015; Yazdanfar \& Öhman, 2015; Gherhes, Williams, Vorley \& Vasconcelos, 2016; Jitmaneeroj, 2016; Padachi \& Bhiwajee, 2016; Valaei, Rezaei \& Ismail, 2017). However, the biggest challenge which some MSMEs face is being able to sustain their performance, and hence succeed and survive (Ates, Garengo, Cocca \& Bititci, 2013; Lampadarios, 2016). Part of the failure of MSMEs may have nothing to do with the well-documented problems of lack of access to finance; markets and appropriate infrastructure. Frazer, Weaven and Grace (2012) argue that having access to finance will not always result in the success and survival of an enterprise since such finance may result in the enterprise having higher levels of debt if the source is a loan. Thus, the enterprise may get into further financial distress if it fails to repay the loan.

Previous researches highlights the causes of failure of MSMEs as limited access to finance and high cost of finance; lack of marketing skills and market knowledge; inadequate management and entrepreneurial skills; lack of access to infrastructure; lack of access to land; lack of information; and a hostile regulatory environment (Mudavanhu, Bindu, Chigusiwa \& Muchabaiwa, 2011; Baporikar, Nambira \& Gomxos, 2016; Lampadarios, 2016). Ates et al., (2013) attributes part of the failure of MSMEs to strategic management issues such as failure to monitor business performance. While most previous studies have tended to focus on identifying the causes of failure for MSMEs, this research attempts to identify through literature review, the factors which may be critical to the success of MSMEs in the retail sector.

The study is guided by the goal theory and the stakeholder theory. The goal theory considers the enterprise as a rational set of arrangements oriented toward the achievement of goals (Goodman \& Pennings, 1977). The effectiveness of an enterprise is measured in terms of accomplishment of outcomes (Etzioni, 1960). Therefore, the focus is exclusively on the end, which is the achievement of goals, objectives and targets (Henri, 2004). The 
goal theory assumes that an enterprise has ultimate goals that are well defined, few enough to be manageable, understandable and members of the enterprise have a general consensus on these goals, and progress toward these goals is measurable. In this regard, the MSMEs are assumed to have an ultimate goal of operating profitably and in a sustainable manner. The stakeholder theory was first put forward by Freeman in 1984 who argued that an enterprise should consider the interests of all the groups it relates to and not shareholders only. The stakeholder theory identifies employees, customers, suppliers, communities, government, trade unions and providers of finance as other stakeholders of the enterprise other than shareholders (Donaldson \& Preston, 1995; Freeman, 2010; Miles, 2012). Extant literature highlights the need for retail enterprises to have a cordial and symbiotic relationship with their external stakeholders such as customers, suppliers and the government (Wong \& Sohal, 2002; Staughton \& Johnston, 2005; Yu, 2011).

Very few studies have been carried out in the last two decades to discover the key factors that can prevent MSMEs from continual failure (Wild, 2010; Collett, Pandit \& Saarikko, 2014; Lampadarios, 2016) and there is confusion about the factors and actions likely to facilitate their success (Liou \& Smith, 2006; Laitinen, 2011). It appears there is no extant study which conclusively provide the meaning of success to MSMEs entrepreneurs, despite the fact that previous studies spell out the importance of having valid measures of success (Ahmad, Wilson \& Kummerow, 2011). It may be argued that there is also no agreement on what constitutes the best measure of success. Thus, the study will highlight some of the critical success factors which have an influence on the business performance of MSMEs.

\section{Literature Review}

\subsection{Definition of Success and Critical Success Factors}

Before attempting to highlight the critical success factors, it is important to define the concepts of success and critical success factors. The definitions of these concepts are very important in this research since they form the corner stones of the study. Previous research indicates that the definition of the term success in small businesses is not easy (Simpson, Tuck \& Bellamy, 2004; Simpson, Padmore \& Newman, 2012; Gerba \& Viswanadham, 2016; Wach, Stephan \& Gorgievski, 2016). This may be due to the fact that success has a different meaning to different people and depends on the context of the person defining it. Simpson et al. (2004) and Simpson et al. (2012) indicate that the enterprise's success is defined by its growth and profitability. Success can also be defined in terms of a sense of achievement, recognition, job satisfaction, control and flexibility (Greenbank, 2001; Jayawarna, Rouse \& Kitching, 2011; Wach, et al., 2016). Watson, Nicholas, Watson, Hogarth-Scott, and Wilson (1998) argue that a business is successful if it continues to trade and is said to have failed if it ceases trading. However, this definition of success is criticised by Simpson et al. (2004) who argue that the decision to continue or cease trading may be influenced by other factors besides profitability and viability of the business. The aspirations of the owners of an enterprise may be social rather than economic in nature (Nieman \& Nieuwenhuizen, 2009; Wach, et al., 2016). This may be the case especially for MSMEs, where the objective of the owner is sometimes not to create wealth (Blackburn, Hart \& Wainwright, 2013; Davidsson, 1991). Entrepreneurs may start a business in order to become famous rather than to create wealth (Gerba \& Viswanadham, 2016) or just to create employment for family members (Papadaki \& Chami, 2002).

Lack of consensus on the definition of success among researchers makes the study of success in small businesses difficult (Rogoff, Lee \& Suh, 2004; Gerba \& Viswanadham, 2016). There is also no agreement on what constitutes the best measure of success (Ahmad, et al., 2011). The several meanings of success suggest that the best measure of success is as defined by the owner of the small business (Simpson et al., 2004; Simpson et al., 2012; Gerba \& Viswanadham, 2016; Wach et al., 2016) and not outsiders (Simpson et al., 2004; Simpson et al., 2012). However, this study assumes that the owner/managers of MSMEs are rational investors whose business motive is to create and maximise their wealth. Very few studies have been carried out in the last two decades to discover the key factors that can prevent enterprises from continual failure (Wild, 2010; Collett, Pandit \& Saarikko, 2014). There is confusion about the factors and actions likely to facilitate the success of enterprises (Liou \& Smith, 2006; Laitinen, 2011; Parnell, Long \& Lester, 2015). Thus, it seems that as of now there is no study that has been carried out to conclusively provide the meaning of success to MSMEs entrepreneurs. This is despite the fact that previous studies spell out the importance of having valid measures of success (Ahmad, Wilson \& Kummerow, 2011).

The concept of a critical success factor was coined as long back as 1961 by Daniel and was made popular by Rockart in 1979 (Quesada \& Gazo, 2007). Rockart (1979) defined critical success factors as the limited number of areas in which results ensure successful competitive performance for the enterprise. Oakland (2003) defines critical success factors as those elements which should be examined to ensure effective management and 
attainment of organisational goals. Masocha and Charamba (2014) furthermore highlights that a key success factor is anything which enables an enterprise to get business. Lampadarios (2016) and Tracy (2007) mentions that each industry has its own critical success factors. Therefore, this research attempts to identify those critical success factors which may be relevant to MSMEs in the retail sector.

\subsection{Critical Success Factors For retail MSMES}

A review of extant literature suggests that the critical success factors for the performance of retail MSMEs are commitment of the owner/manager, employee commitment, business planning, management of information, management of revenue, management of costs, innovation, management of customers, management of suppliers, management of competitors, the enterprise's pool of resources, conformance to regulations and management of sources of finance. Literature on each of these critical success factors is presented below.

\subsubsection{Commitment of the Owner/Manager}

Research suggest that MSMEs which have a family CEO tend to report high return on assets and return on investment when compared to enterprises where the CEO is not a family member and this return is even reduced where the family CEO is not the founder (Hansson, Liljeblom, \& Martikainen, 2011). This suggests that the owner of a business is likely to make decisions that result in long term success and survival of the business. This also depends on the motivation for starting the business, whether the owner was pushed or pulled by certain factors (Asah et al., 2015). The management skills rather than technical skills (Asah, et al., 2015; Bager, Jensen, Nielsen \& Larsen, 2015) and the growth motivation of founders is very important and are the leading factors in the growth, success and survival of an enterprise (Feindt, Jeffcoate, \& Chappell, 2002; Halabi, Barrett, \& Dyt, 2010; Isaga et al., 2015; Gherhes et al., 2016). In addition to owner involvement, lean management structure results in optimal performance in MSMEs (Coles, Daniel \& Naveen, 2008; Guest, 2009). Top management in MSMEs may refer to the owner of the MSME or manager or both. The owner/manager is likely to have a clear picture of the business (Berko, Ashie \& Kodjo, 2016). The owner /manager of the MSME is the agent of change and can influence behaviour of people who work for the enterprise so that their activities focus on the key stakeholders (Bassioni., Price \& Hassan, 2005). The behaviour of the employees can be influenced through communicating the enterprise's strategy, training of employees, and putting in place incentives in order to avoid resistance by the employees (Turner, Bititci \& Nudurupati, 2005; Watts \& McNair-Connolly, 2012).

\subsubsection{Employee Commitment}

Employee commitment is vital for the success and survival of any enterprise (Krüger \& Rootman, 2010; Valaei \& Rezaei, 2016). There is need for creating a business environment which promote commitment of employees if MSMEs are to survive (Bosch, Tait \& Venter, 2006). Owner/managers of MSMEs can promote employee commitment by listening to and supporting their employees, creating an environment which inspire employees to work hard, having an interest in each employee, not being negative, and appreciating each employee's work (Krüger \& Rootman, 2010). Thus, it can be argued that employee commitment is a hallmark of successful MSMEs.

The attributes of employee commitment identified in extant literature are employee participation in decision-making, autonomy, job satisfaction, level of employee motivation, employee loyalty, recognition, feedback, employee learning and professional growth (Krüger \& Rootman, 2010; Berko, et al, 2016; Valaei \& Rezaei, 2016). Failure to motivate employees leads to employee dissatisfaction and low commitment resulting in undesirable outcomes such as absenteeism, high staff turnover, reporting for work late, lack of willingness to work overtime or go an extra mile, and generally low productivity (Bartunek \& Spreitzer, 2006; Hutchinson et al., 2015).

\subsubsection{Business Planning}

A business plan is an important ingredient for any enterprise which seeks to succeed in its operations and therefore MSMEs are not an exception (Blackburn, et al., 2013; Uddin \& Bose, 2013; Ahmad, Mohamed \& Omar, 2015). There is overwhelming evidence linking business planning in MSMEs to growth and ability to succeed and survive (Foreman-Peck, Makepeace \& Morgan, 2006; Mazzarol, Reboud \& Soutar, 2009; Lampadarios, 2016). However, there is also an argument that strategic business planning is not feasible in MSMEs because of the volatile business environment in which most MSMEs operate (Pekkola, Saunila \& Rantanen, 2016). As a result most MSMEs shun formal planning (Parnell et al., 2015). Previous research indicates existence of a clear relationship between lack of planning by MSMEs and business failure (Jayawarna, Macpherson \& Wilson, 2007). Planning enables the enterprise to develop, communicate, implement, and improve its strategy in order to achieve the enterprise's performance objectives (Talib, Ali, \& Idris, 2014). The 
business plan should focus on the needs of the enterprise's important stakeholders such as customers, suppliers, government regulators, employees, and the shareholders (Talib et al., 2014).

\subsubsection{Management of Information}

Management of key and strategic information is very important for any enterprise's success and survival (Bengesi \& Le Roux, 2014; Zerfass \& Winkler, 2016). There is an argument that management of market intelligence information on customers, suppliers and competitors makes it possible for MSMEs to explore new opportunities by focussing on new processes, products and services (Keskin, 2006; Li \& Zhou, 2010; Ndubisi \& Iftikhar, 2012). This innovation can only occur in an enterprise where everyone has easy access to information and seeking, sharing and utilising new information is encouraged and rewarded (Dobni, 2008).Thus, information is an important ingredient in a retail MSME's quest to provide superior and competitive goods which meet customer needs. There is also need for the sharing of information between the company and its external stakeholders such as suppliers and customers (Zerfass \& Winkler, 2016). For example, if manufacturers and retailers share information on market competition, market demand and customer preference, there is a very high chance that the market will be supplied with goods and services which meet customer needs and satisfaction (Lagrosen, 2005; McEvily \& Marcus, 2005; Lin , Chen \& Chiu, 2010; Bayraktar, 2015). Lakhal, Pasin \& Limam (2006) highlight that gathering and analysing information has an effect on business performance. However, information management systems for MSMEs should be very simple since MSMEs lack adequate IT related resources needed for a complex information management system (Alattar, Kouhy \& Innes, 2009).

\subsubsection{Management of Revenue}

Revenue management is an area of management accounting which focuses on improving revenue and managing the enterprise's limited capacity in order to enhance the chances of long term survival (Ng, Harrison \& Akroyd, 2013). This is done by offering an affordable product or service at the right time and which meets the needs of the customers ( $\mathrm{Ng}$, et al., 2013). This is an appropriate way of increasing the MSMEs' profitability given that the enterprises attach less importance to the management accounting role of co-ordination, control and accountability due to their small size and close control by the owner/manager (Otley, 2007).

The generation of revenue results in the improvement of the cash flow position for the enterprise $(\mathrm{Ng}$, et al., 2013) and this is vital for its survival (Bhandari \& Iyer, 2013). Revenue management involves collecting and analysing data to get information on the trends, habits, and demand patterns of customers in order to assess customer profitability ( $\mathrm{Ng}$, et al., 2013). The data is then analysed using management accounting techniques such as demand forecasting, linear programming, the BSC, cost-volume analysis and predictive budgets (Drury, 2004; Otley, 2007; Ng, et al., 2013).

\subsubsection{Management of Costs}

Cost management results in the efficient operation of the business. For example, cost cutting measures applied by a struggling company during a scheme of business reorganisation can result in performance improvement and therefore recovery of the business (Smith \& Graves, 2005; Alfaro, Ortiz \& Poler, 2007; Laitinen, 2011). Cost control is also considered a critical success factor by Feindt, et al. (2002). Biggart, Burney, Flanagan and Harden (2010) assert that one of the primary means of improving an enterprise's profitability is to control costs, mainly inventory and store expenses. Inventory management will consist of managing shrinkage through in-store audits (Ng, et al., 2013). This is likely to be a very important factor for MSMEs in the retail sector.

\subsubsection{Innovation}

Innovation is a requisite for sustainable long term business performance (Saunila, 2016). The success and survival of an enterprise will depend on its innovation capability (Talke, Salomo \& Kock, 2011; Al-Ansari, Pervan \& Xu, 2013; Bulak, Turkyilmaz, Satir, Shoaib \& Shahbaz, 2016). There is an argument that innovation is a life blood of an enterprise's growth and survival as it is central in creating value and competitive advantage for the enterprise (Baregheh, Rowley \& Sambrook, 2009). Previous studies established a positive relationship between business performance of MSMEs and the extent of innovation (Otero-Neira, Lindman \& Fernández, 2009; Forsman \& Temel, 2011; Kotey, 2014). However, other researchers found a negative or no relationship between business performance and the level of innovation (Freel, 2000).

An innovative enterprise is one which constantly seeks new ideas that result in new products and ways of doing business (Shirokova, Vega \& Sokolova, 2013). MSMEs need to develop new abilities, entrepreneurial orientation, entrepreneurial culture and entrepreneurial mind-set in order to survive and grow especially when faced with constraint of resources (Shirokova, et al., 2013). Masocha and Charamba (2014) identify constant innovation as a critical factor for MSMEs to successfully compete with large enterprises. They posit that this innovation should 
focus on marketing strategies, internal processes, and maximising delivery of customer benefits and satisfaction.

\subsubsection{Management of Customers}

In order for an enterprise to become competitive and therefore succeed, there is need to improve customer service (Alfaro, et al., 2007; Lampadarios, 2016). Enterprises which have a successful growth usually have close contact with their customers and are committed to quality of products and services (Feindt, et al., 2002; Bulak, et al., 2016). The enterprise should develop a close and trusted relationship with its customers for it to achieve a higher performance (Azmat \& Samaratunge,2009; Azmat \& Samaratunge, 2013; Shi \& Yu, 2013) and this can be done through a process of networking with customers (Taipale-Erävala, Heilmann \& Lampela, 2014). Therefore, it is plausible that the importance of developing a relationship with customers can never be over emphasised.

Customer management should aim at developing customer loyalty and trust (Hutchinson, et al., 2015). Customer loyalty will lead to customer retention which is critical for the success of any enterprise (Azmat \& Samaratunge, 2013). A loyal customer will always buy from the enterprise even if there are better alternative goods or services offered by the company's competitors (Hutchinson, et al., 2015). Therefore, the MSMEs should be customer focused and concentrate on satisfying customers so as to retain current customers and acquire new customers leading to higher market performance (Laukkanen, Nagy, Hirvonen, Reijonen, \& Pasanen, 2013).

The owner-manager of a MSME should have a good knowledge of the market and industry being served by the enterprise. A positive interaction with customers will result in MSMEs delivering goods and services which meet customer needs. For example, enterprises wishing to develop new products need to depend on customers and market research in order to know customers' future needs (Taipale-Erävala, et al., 2014).

\subsubsection{Management of Suppliers}

A critical review of performance measurement frameworks seems to suggest that management of suppliers is not highlighted to a very large extent as a critical success factor for business performance in MSMEs. For example, the most common performance measurement frameworks, the BSC by Kaplan and Norton (1992) and the Results Determinant Framework by Brignall, Fitzgerald, Johnston \& Silvestro (1991) do not consider suppliers in their perspectives. Supplier management is one of the important drivers of financial performance (Quesada \& Gazo, 2007; Atristain \& Rajagopal, 2010; Shi \& Yu, 2013). Enterprises should develop a relationship with their suppliers for them to achieve a competitive advantage and long term organisational performance (Temtime \& Solomon, 2002; Tari, Molina \& Castejon, 2007; Talib, et al., 2014; Bulak, et al., 2016).

\subsubsection{Management of Competitors}

Management of the enterprise's competitors is necessary for the success and long term survival of the enterprise (Miles, 2012). Hence, enterprises should not focus on their customers only but should place equal importance on their competitors as well if they are to gain competitive advantage in the business environment (Matanda \& Ndubisi, 2009). Management of competitors by the enterprises involves knowledge of who the competitors are and their business operations (Masocha \& Charamba: 2014). The enterprise should aim to offer unique and better products than competitors if it is to survive in the market place (Nieman \& Nieuwenhuizen, 2009). Masocha and Charamba (2014) further argue that the enterprise should identify the weaknesses and gaps left by the competitor and capitalise on the weaknesses and gaps. The management of competitors may be done through benchmarking. Tucker and Pitt (2009) view benchmarking as a process of searching the industry's best practice against which the enterprise's performance will be measured. In simple terms, benchmarking implies that the enterprise compares its performance to that of its competitors (Amir, 2011). Benchmarking is very important since a fundamental requirement of an enterprise's business growth is having a better performance in relation to competitors (Laukkanen, et al., 2013; Taschner, 2016).

Benchmarking can be internal or external (Hegazy \& Hegazy, 2012). External benchmarking is when the enterprise compares its performance to external standards, which are the best practice for the industry (Hegazy \& Hegazy, 2012; Laukkanen, et al., 2013). Internal benchmarking is when the enterprise compares its performance against its own standards which are set by the management (Hegazy \& Hegazy, 2012; Laukkanen, et al., 2013). Tucker and Pitt (2009) posit that only external benchmarking results in sustainable competitive advantage and high performance. In addition to benchmarking, MSMEs should also network with their competitors and share knowledge, information and other resources (Bayraktar, 2015; Gunawan, Jacob \& Duysters, 2016).

\subsubsection{The Enterprise's Pool of Resources}

The resource-based theory suggests that the performance and growth of an enterprise is driven by the resources possessed by that enterprise (Atristain \& Rajagopa, 2010; Barney, Ketchen \& Wright, 2011; Hsu, Tan, Laosirihongthong \& Leong, 2011; Tan, Smyrnios \& Xiong, 2014; Yazdanfar \& Öhman, 2015). A company's 
capability depends to a greater extent on its pool of tangible and intangible assets (Ratnatunga, Gray \& Balachandran, 2004). These resources are financial, physical, human, organisational, and technological. Therefore, the performance of enterprises in the same industry is different because of the differences in the resources and capabilities they possess (Kohlbacher \& Gruenwald, 2011; Shirokova, et al., 2013).

Previous studies indicate that in order for an enterprise to be competitive and hence successful, there is a need for it to acquire unique resources which cannot be replicated or substituted by competitors (Caldeira \& Ward, 2003; Edelman, Brush \& Manolova, 2005; Davidsson, Achtenhagen \& Naldi, 2006; Blackburn, et al., 2013, Shirokova, et al., 2013; Shi \& Yu, 2013; Kotey, 2014). However, it is important to compare the MSME's performance to its physical capability since most MSMEs have limited resources which can be the cause for poor performance (Taticchi \& Balachandran, 2008).

Lack of resources is often cited as one of the major causes of poor business performance and therefore failure of MSMEs (Kohlbacher \& Gruenwald, 2011; Ratnatunga, et al., 2004; Shirokova, et al., 2013). This seems to be an over generalisation. It is not only availability of resources which is important for success and growth of businesses, but how these resources are used as well (Shirokova, et al., 2013). Two or more MSMEs may have the same set of tangible resources and operate under the same external environment but produce different business performance (Ratnatunga, et al., 2004). The importance of resources varies among MSMEs and depends on the enterprise's goals (Tan, et al., 2014). Researchers should therefore be interested in knowing which resources have the greatest impact on the performance of an enterprise and how they have an influence on the performance.

A review of the literature seems to point out that intangible resources are the most important and unique resources of any enterprise. Ratnatunga, et al. (2004) found that enterprises which paid more attention to soft or intangible resources were more successful than those which did not. Examples of soft or intangible resources are employees, knowledge and skills, a strong business base, reputation and business relationships, brand equity (Ratnatunga, et al., 2004; Kotey, 2014). Previous studies highlight that knowledge based intangible resources such as know-how, technologies, patents and licenses, qualified personnel and professional managers are the most important resources which drive the performance of an enterprise (Shirokova, et al., 2013; Kotey, 2014). These knowledge based resources can be acquired through training, research and development and continuous organisational learning (Shirokova, et al., 2013). Intangible resources may not be imitated and therefore give an enterprise a competitive advantage over its competitors.

A number of research studies highlight the positive effect of a learning culture on enterprise performance (Wang, 2008; Tan, et al., 2014). It can be argued that an enterprise which pays particular attention to knowledge based resources conforms to Kaplan and Norton (1992)'s learning and growth perspective. For example, the ability of management stands out as a resource factor on its own. This is because owner/managers are the ones who put together scarce resources and their ability to do so efficiently and effectively determine the success of an enterprise (Kelliher \& Reinl, 2009; Mazzarol, Reboud, \& Soutar, 2009; Blackburn, et al., 2013; Ramukumba, 2014).

\subsubsection{Conformance to Regulations}

MSMEs should conform to regulatory authorities in order for them to succeed in their business endeavours (Lampadarios, 2016). Examples of regulatory authorities are government departments like tax authorities, standards setting, and monitoring boards, environment monitoring boards and local authorities. A considerable number of MSMEs in Zimbabwe face closure every year when the Zimbabwe Revenue Authority fines them heavily for failing to comply with various tax laws of the country (Utaumire, Mashiri \& Mazhindu; 2013; Nyamwanza, Mavhiki, Mapetere, \& Nyamwanza, 2014). Therefore compliance to the country's trade regulations could ensure that an enterprise avoids unnecessary penalties and operate profitably leading to its long term success.

\subsubsection{Management of Sources of Finance}

Non-availability of finance is always cited as one of the reasons contributing to the failure of MSMEs (Olawale \& Garwe, 2010; Masocha \& Charamba, 2014; Ramukumba, 2014). The fact that MSMEs cannot easily get finance from financial institutions (Ramukumba, 2014) means that MSMEs should establish good relationships with their suppliers so as to get goods on credit (Ramukumba, 2014). Mere access to financial resources is not enough condition for success of an enterprise. The financial resources may need to be utilised effectively and efficiently in order to result in a successful enterprise. Some MSMEs with adequate resources have often been found to misuse those resources leading to failure of the enterprise (Stokes \& Wilson, 2006; Ramukumba, 2014). On the other hand, Masocha and Charamba (2014) found that foreign owned MSMEs in South Africa performed 
better than local MSMEs despite the fact that local MSMEs had better access to financial resources than MSMEs owned by foreigners. There is an argument for a shift in focus from challenges related to lack of financial resources to viability of the business, entrepreneurial abilities of the owner/managers and use of modern management techniques to enhance performance and survival of MSMEs (Ramukumba, 2014:20).

\subsubsection{Level of profit}

Although profitability may be regarded as the main objective of any profit making enterprise, it may also be viewed as a CSF for the sustainable performance and survival of MSMEs. Historically, most MSMEs assess their performance based on level of profit (Kaplan \& Norton, 1992; Atkinson, Waterhouse \& Wells, 1997; Henri, 2004; Halab, Barrett \& Dyt, 2010). Profit measures are used as tools for motivating and controlling the performance of divisions, managers and employees so that everyone in the company channels his or her energy towards achieving the organisational goals (Otley, 2001; Drury, 2004; Otley, 2007). Thus, performance appraisal of each manager or division is based on the output of the responsibility centre (Drury, 2004).

There seem to be no consensus on the effectiveness of the use of profit measures to motivate and control the activities of managers and employees of an enterprise. For example, Otley (2001) gives conflicting remarks when he argues on one hand that financial performance measures such as profitability reflected in an enterprise's financial statements capture controllable aspects of business performance. On the other hand he argues that profitability measures are measures of outcome and cannot control performance. He advocates for measurement of activities that drive performance rather than measurement of outcomes of performance. Some researchers also argue that profitability measures may not be regarded as critical success factors as they assess past performance rather than predicting future performance (Kaplan \& Norton, 1992; Otley, 2007).

\section{Conclusion}

The study has identified the factors that may be considered as critical in the success of MSMEs in the retail sector. The factors identified as critical in the success of MSMEs in the retail sector were commitment of the owner/manager, business planning, management of information, management of revenue, management of costs, innovation, management of customers, management of suppliers, management of competitors, the enterprise's pool of resources, management of regulators and management of sources of finance. The study also attempted to highlight the influence of each of these factors in enhancing the success and survival of MSMEs. The study does not claim to provide an exhaustive list of all factors critical to the success of MSMEs. The factors influencing the performance of MSMEs are so numerous and sometimes so complex that no study may identify all the possible factors. However, the factors identified in this study are considered as fundamental in the performance and success of MSMEs in the retail sector.

There is need for following up this review of literature with an empirical study in order to establish the extent to which MSMEs in the retail sector perceive these factors as critical in the success of their operations. Another study may be carried out to develop a performance measurement framework for MSMEs in the retail sector based on the critical success factors identified in this study.

\section{Contribution and Implications}

The study identified the possible combination of factors which if managed well, may contribute to the success of MSMEs in the retail sector. Most previous researches focused on the individual factors in isolation of other factors. Those studies which looked at a combination of factors seemed not to provide a broad range of factors focusing on the MSMEs' stakeholders. Although, the study does not claim to have exhausted all possible factors which may influence the success of MSMEs in the retail sector, monitoring and managing the factors identified in this study may go a long way in steering MSMEs toward sustainable growth. Thus, owner/managers and other partners who support the cause of MSMEs should make an effort to at least channel their energy towards managing the factors identified in this study.

\section{References}

Ahmad, N. H., Wilson, C., \& Kummerow, L. (2011). Assessing the dimensionality of business success: The perspectives of Malaysian SME owner-managers. Journal of Asia-Pacific Business, 12(3), 207-224. http://dx.doi.org/10.1080/10599231.2011.586855

Al-Ansari, Y., Pervan, S., \& Xu, J. (2013). Innovation and business performance of SMEs: The case of Dubai. Education, Business and Society: Contemporary Middle Eastern Issues, 6(3/4), 162-180. http://dx.doi.org/10.1108/EBS-04-2013-0012

Alattar, J. M., Kouhy, R., \& Innes, J. (2009). Management accounting information in micro enterprises in Gaza. 
Journal of Accounting \& Organizational Change, 5(1), 81-107. http://dx.doi.org/10.1108/18325910910932223

Alfaro, J., Ortiz, A., \& Poler, R. (2007). Performance measurement system for business processes. Production Planning and Control, 18(8), 641-654. http://dx.doi.org/10.1080/09537280701599772

Asah, F., Fatoki, O. O., \& Rungani, E. (2015). The impact of motivations, personal values and management skills on the performance of SMEs in South Africa. African Journal of Economic and Management Studies, 6(3), 308-322. http://dx.doi.org/10.1108/AJEMS-01-2013-0009

Ates, A., Garengo, P., Cocca, P., \& Bititci, U. (2013). The development of SME managerial practice for effective performance management. Journal of Small Business and Enterprise Development, 20(1), 28-54. http://dx.doi.org/10.1108/14626001311298402

Atkinson, A. A., Waterhouse, J. H., \& Wells, R. B. (1997). A stakeholder approach to strategic performance measurement. MIT Sloan Management Review, 38(3), 25-38.

Atristain, C., \& Rajagopal. (2010). Conceptual Perspectives on Organizational Performance and Competitiveness of SMEs in Mexico. Journal of Transnational Management, 15(4), 322-349. http://dx.doi.org/10.1080/15475778.2010.525490

Azmat, F., \& Samaratunge, R. (2009). Responsible entrepreneurship in developing countries: Understanding the realities and complexities. Journal of Business Ethics, 90(3), 437-452. http://dx.doi.org/10.1007/s10551-009-0054-8

Azmat, F., \& Samaratunge, R. (2013). Exploring customer loyalty at bottom of the pyramid in South Asia. Social Responsibility Journal, 9(3), 379-394. http://dx.doi.org/10.1108/SRJ-09-2011-0077

Bager, T. E., Jensen, K. W., Nielsen, P. S., \& Larsen, T. A. (2015). Enrollment of SME managers to growth-oriented training programs. International Journal of Entrepreneurial Behavior \& Research, 21(4), 578-599. http://dx.doi.org/10.1108/IJEBR-12-2014-0224

Baporikar, N., Nambira, G., \& Gomxos, G. (2016). Exploring factors hindering SMEs' growth: evidence from Namibia. Journal of Science and Technology Policy Management, 7(2), 190-211. http://dx.doi.org/10.1108/JSTPM-11-2015-0036

Baregheh, A., Rowley, J., \& Sambrook, S. (2009). Towards a multidisciplinary definition of innovation. Management decision, 47(8), 1323-1339. http://dx.doi.org/10.1108/00251740910984578

Barney, J. B., Ketchen, D. J., \& Wright, M. (2011). The future of resource-based theory revitalization or decline?" Journal of management, 37(5), 1299-1315. http://dx.doi.org/10.1007/s10551-009-0054-8

Bartunek, J. M., \& Spreitzer, G. M. (2006). The Interdisciplinary Career of a Popular Construct Used in Management Empowerment in the Late 20th Century. Journal of Management Inquiry, 15(3), 255-273.

Bassioni, H. A., Price, A. D., \& Hassan, T. M. (2005). Building a conceptual framework for measuring business performance in construction: an empirical evaluation. Construction Management and Economics, 23(5), 495-507. http://dx.doi.org/10.1080/0144619042000301401

Bayraktar, S. (2015). New regulations: challenge or opportunity for Turkish SMEs? Qualitative Research in Financial Markets, 7(2), 173-190. http://dx.doi.org/10.1108/QRFM-05-2014-0015

Bengesi, K. M., \& Le Roux, I. (2014). Strategic entrepreneurial response of small and medium enterprises in developing economies. International Journal of Business and Management, 9(2), 153-165

Berko O. D, O., Ashie, A., \& Kodjo K. E., (2016). The propensity to participate in formal training programmes: Evidence from small and medium-sized enterprises (SMEs) in Ghana. World Journal of Entrepreneurship, Management and Sustainable Development, 12(4), 344-358. http://dx.doi.org/10.1108/WJEMSD-07-2016-0033

Bhandari, S. B., \& Iyer, R. (2013). Predicting business failure using cash flow statement based measures. Managerial Finance, 39(7), 667-676. http://dx.doi.org/10.1108/03074351311323455

Biggart, T. B., Burney, L. L., Flanagan, R., \& Harden, J. W. (2010). Is a Balanced Scorecard Useful in a Competitive Retail Environment?" Management Accounting Quarterly, 12(1), 1-12

Blackburn, R. A., Hart, M., \& Wainwright, T. (2013). Small business performance: business, strategy and owner-manager characteristics. Journal of small business and enterprise development, 20(1), 8-27. http://dx.doi.org/10.1108/14626001311298394 
Bosch, J., Tait, M., \& Venter, E. (2006). Business management: An entrepreneurial perspective. Port Elizabeth: Lectern.

Brignall, T., Fitzgerald, L., Johnston, R., \& Silvestro, R. (1991). "Performance Measurement in Service Businesses. Management Accounting, 69(10), 34-36.

Bulak, M. E., Turkyilmaz, A., Satir, M., Shoaib, M., \& Shahbaz, M. (2016). Measuring the performance efficiency of Turkish electrical machinery manufacturing SMEs with frontier method. Benchmarking: An International Journal, 23(7), 2004-2026. http://dx.doi.org/10.1108/BIJ-09-2015-0089

Caldeira, M. M., \& Ward, J. M. (2003). Using resource-based theory to interpret the successful adoption and use of information systems and technology in manufacturing small and medium-sized enterprises. European Journal of Information Systems, 12(2), 127-141.

Coles, J. L., Daniel, N. D., \& Naveen, L. (2008). Boards: Does one size fit all?” Journal of Financial Economics, 87(2), 329-356. http://dx.doi.org/10.1016/j.jfineco.2006.08.008

Collett, N., Pandit, N. R., \& Saarikko, J. (2014). Success and failure in turnaround attempts. An analysis of SMEs within the Finnish Restructuring of Enterprises Act. Entrepreneurship \& Regional Development, 26(1-2), 123-141.

Davidsson, P. (1991). Continued entrepreneurship: ability, need and opportunity as determinants of small firm growth. Journal of Business Venturing, 6(6), 405-429. http://dx.doi.org/10.1016/0883-9026 (91)90028-C

Davidsson, P., Achtenhagen, L., \& Naldi, L. (2006). What do we know about small firm growth? in The life cycle of entrepreneurial ventures, 361-398. http://dx.doi.org/10.1007/978-0-387-32313-8_13

Dobni, C. B. (2008). Measuring innovation culture in organizations: The development of a generalized innovation culture construct using exploratory factor analysis", European Journal of Innovation Management, 11(4), 539-559. http://dx.doi.org/10.1108/14601060810911156

Donaldson, T., \& Preston, L. E. (1995). "The stakeholder theory of the corporation: Concepts, evidence, and implications. Academy of management Review, 20(1), 65-91.

Edelman, L. F., Brush, C. G., \& Manolova, T. (2005). Co-alignment in the resource-performance relationship: strategy as mediator. Journal of Business Venturing, 20(3), 359-383. http://dx.doi.org/10.1016/j.jbusvent.2004.01.004

Etzioni, A. (1960). Two approaches to organizational analysis: A critique and a suggestion. Administrative Science Quarterly, 257-278. http://dx.doi.org/10.2307/2390780

Feindt, S., Jeffcoate, J., \& Chappell, C. (2002). Identifying success factors for rapid growth in SME e-commerce", Small Business Economics, 19(1), 51-62. http://dx.doi.org/10.1023/A:1016165825476

Foreman-Peck, J., Makepeace, G., \& Morgan, B. (2006). Growth and profitability of small and medium-sized enterprises: Some Welsh evidence. Regional Studies, 40(4), 307-319.

Forsman, H., \& Temel, S. (2011). Innovation and business performance in small enterprises: an enterprise-level analysis. International Journal of Innovation Management, 15(3), 641-665. http://dx.doi.org/10.1142/S1363919611003258

Frazer, L., Weaven, S., \& Grace, D. (2012). Survival of the fittest: The performance of franchised versus independent small business during economic uncertainty and recovery, Griffith University.

Freel, M. S. (2000). Do small innovating firms outperform non-innovators?", Small Business Economics, 14(3), 195-210. http://dx.doi.org/10.1023/A:1008100206266

Freeman, R. E. (2010). Strategic management: A stakeholder approach. Cambridge University Press.

Freeman, R.E (1984). Strategic management: A stakeholder approach. Boston: Pitman Publications.

Gerba, Y. T., \& Viswanadham, P. (2016). Performance measurement of small scale enterprises: Review of theoretical and empirical literature. IJAR, 2(3), 531-535.

Gherhes, C., Williams, N., Vorley, T., \& Vasconcelos, A. C. (2016). Distinguishing micro-businesses from SMEs: a systematic review of growth constraints. Journal of Small Business and Enterprise Development, 23(4), 939-963.

Goodman, P. S., \& Pennings, J. M. (1977). New perspectives on organizational effectiveness. Jossey-Bass Incorporated Pub. 
Greenbank, P. (2001). Objective setting in the micro-business", International Journal of Entrepreneurial Behavior \& Research, 7(3). 108-127. http://dx.doi.org/10.1108/EUM0000000005531

Guest, P. M. (2009). The impact of board size on firm performance: Evidence from the UK. The European Journal of Finance, 15(4), 385-404. http://dx.doi.org/10.1080/13518470802466121

Gunawan, T., Jacob, J., \& Duysters, G. (2016). Network ties and entrepreneurial orientation: Innovative performance of SMEs in a developing country. International Entrepreneurship and Management Journal, 12(2), 575-599. http://dx.doi.org/10.1007/s11365-014-0355-y

Habibah Abdul Talib, H., Anuar Mohd Ali, K., \& Idris, F. (2014). Critical success factors of quality management practices among SMEs in the food processing industry in Malaysia. Journal of Small Business and Enterprise Development, 21(1), 152-176. http://dx.doi.org/10.1108/JSBED-10-2013-0162

Halabi, A. K., Barrett, R., \& Dyt, R. (2010). Understanding financial information used to assess small firm performance: An Australian qualitative study. Qualitative Research in Accounting \& Management, 7(2), 163-179. http://dx.doi.org/10.1108/11766091011050840

Hansen, B., \& Hamilton, R. T. (2011). Factors distinguishing small firm growers and non-growers. International Small Business Journal, 29(3), 278-294. http://dx.doi.org/10.1177/0266242610381846

Hegazy, M. A. (2012). The development of key financial performance indicators for UK construction companies. Hegazy, Mohamed and Hegazy, Sherif. The development of key financial performance indicators for UK construction companies. Accounting, Accountability \& Performance, 17, 49-77.

Henri, J. (2004). Performance measurement and organizational effectiveness: Bridging the gap", Managerial Finance, 30(6), 93-123. http://dx.doi.org/10.1108/03074350410769137

Hsu, C., Tan, K. C., Laosirihongthong, T., \& Leong, G. K. (2011). Entrepreneurial SCM competence and performance of manufacturing SMEs. International Journal of Production Research, 49(22), 6629-6649. http://dx.doi.org/10.1080/00207543.2010.537384

Hutchinson, K., Donnell, L.V., Gilmore, A. and Reid, A. (2015). Loyalty card adoption in SME retailers: the impact upon marketing management. European Journal of Marketing, 49(3/4), 467-490. http://dx.doi.org/10.1108/EJM-06-2013-0321

Isaga, N., Masurel, E., \& Van Montfort, K. (2015). Owner-manager motives and the growth of SMEs in developing countries: Evidence from the furniture industry in Tanzania. Journal of Entrepreneurship in Emerging Economies, 7(3), 190-211. http://dx.doi.org/10.1108/JEEE-11-2014-0043

Jayawarna, D., Macpherson, A., \& Wilson, A. (2007). Training commitment and performance in manufacturing SMEs: Incidence, intensity and approaches. Journal of Small Business and Enterprise Development, 14(2), 321-338. http://dx.doi.org/10.1108/14626000710746736

Jayawarna, D., Rouse, J., \& Kitching, J. (2011). Entrepreneur motivations and life course. International Small Business Journal, 31(1), 34-56. https://doi.org/10.1177/0266242611401444

Jitmaneeroj, B. (2016). Reform priorities for corporate sustainability: environmental, social, governance, or economic performance? Management Decision, 54(6), 1497-1521. http://dx.doi.org/10.1108/MD-11-2015-0505

Kaplan, R. S., \& Norton, D. P. (1992). The Balanced Scorecard - Measures that Drive Performance The Balanced Scorecard - Measures. Harvard business review, 70(1), 71-79.

Kelliher, F., \& Reinl, L. (2009). A resource-based view of micro-firm management practice. Journal of Small Business and Enterprise Development, 16(3), 521-532. http://dx.doi.org/10.1108/14626000910977206

Keskin, H. (2006). Market orientation, learning orientation, and innovation capabilities in SMEs: An extended model. European Journal of Innovation Management, 9(4), 396-417. http://dx.doi.org/10.1108/14601060610707849

Kohlbacher, M., \& Gruenwald, S. (2011). Process ownership, process performance measurement and firm performance. International Journal of Productivity and Performance Management, 60(7), 709-720. http://dx.doi.org/10.1108/17410401111167799

Kotey, B. (2014). Small business innovation in the hostile environment of Australia's drought stricken rural communities. Australasian Journal of Regional Studies, 20(2), 325-351

Kruger, J., \& Rootman, C. (2010). How do small business managers influence employee satisfaction and 
commitment? Acta Commercii, 10(1), 59-72. http://dx.doi.org/10.4102/ac.v10i1.114

Lagrosen, S. (2005). Customer involvement in new product development: A relationship marketing perspective. European Journal of Innovation Management, 8(4), 424-436. http://dx.doi.org/10.1108/14601060510627803

Laitinen, E. K. (2011). Effect of reorganization actions on the financial performance of small entrepreneurial distressed firms. Journal of Accounting \& Organizational Change, 7(1), 57-95. http://dx.doi.org/10.1108/18325911111125540

Lakhal, L., Pasin, F., \& Limam, M. (2006). Quality management practices and their impact on performance. International Journal of Quality \& Reliability Management, 23(6), 625-646. http://dx.doi.org/10.1108/02656710610672461

Lampadarios, E. (2016). Critical Success Factors for SMEs: An empirical study in the UK chemical distribution industry. International Journal of Business and Management, 11(7), 67-82 http://dx.doi.org/10.5539/ijbm.v11n7p67

Laukkanen, T., Nagy, G., Hirvonen, S., Reijonen, H., \& Pasanen, M. (2013). The effect of strategic orientations on business performance in SMEs. International Marketing Review, 30(6), 510-535.

Li, J. J., \& Zhou, K. Z. (2010). How foreign firms achieve competitive advantage in the Chinese emerging economy: Managerial ties and market orientation. Journal of Business Research, 63(8), 856-862. http://dx.doi.org/10.1016/j.jbusres.2009.06.011

Lin, R., Chen, R., \& Kuan-Shun Chiu, K. (2010). Customer relationship management and innovation capability: an empirical study. Industrial Management \& Data Systems, 110(1), 111-133. http://dx.doi.org/10.1108/02635571011008434

Liou, D., \& Smith, M. (2006). Financial distress and corporate turnaround: a review of the literature and agenda for research. http://dx.doi.org/10.2139/ssrn.925596

Masocha, R., \& Charamba, M. (2014). Challenges and Key Success Factors Of African Descent Foreign-Owned SMES In The Eastern Cape Province Of South Africa: A Case Of Selected Towns. Mediterranean Journal of Social Sciences, 5(4), 59-68. http://dx.doi.org/10.5901/mjss.2014.v5n4p59

Massa, L., Farneti, F., \& Scappini, B. (2015). Developing a sustainability report in a small to medium enterprise: process and consequences. Meditari Accountancy Research, 23(1), 62-91. http://dx.doi.org/10.1108/MEDAR-02-2014-0030

Matanda, J. M., \& Ndubisi, N. O. (2009). Market orientation, supplier perceived value and business performance of SMEs in a Sub-Saharan African nation. Journal of Enterprise Information Management, 22(4), 384-407. http://dx.doi.org/10.1108/17410390910975013

Mazzarol, T., Reboud, S., \& Soutar, G. N. (2009). Strategic planning in growth oriented small firms", International Journal of Entrepreneurial Behavior \& Research, 15(4), 320-345. http://dx.doi.org/10.1108/13552550910967912

McEvily, B., \& Marcus, A. (2005). Embedded ties and the acquisition of competitive capabilities", Strategic Management Journal, 26(11), 1033-1055. http://dx.doi.org/10.1002/smj.484

Miles, S. (2012). Stakeholder: Essentially contested or just confused? Journal of Business Ethics, 108, 285-298. http://dx.doi.org/10.1007/s10551-011-1090-8

Mohd Amir, A. (2011). The indirect effects of PMS design on Malaysian service firms' characteristics and performance. Asian Review of Accounting, 19(1), 31-49. http://dx.doi.org/10.1108/13217341111130542

Mudavanhu, V., Bindu, S., Chigusiwa, L., \& Muchabaiwa, L. (2011). Determinants of small and medium enterprises failure in Zimbabwe: a case study of Bindura. International Journal of Economics Research., 2(5), $82-89$

Ndubisi, O. N., \& Iftikhar, K. (2012). Relationship between entrepreneurship, innovation and performance: Comparing small and medium-size enterprises", Journal of Research in Marketing and Entrepreneurship, 14(2), 214-236. http://dx.doi.org/10.1108/14715201211271429

Ng, F. A., Harrison, J., \& Akroyd, C. (2013). A revenue management perspective of management accounting practice in small businesses. Meditari Accountancy Research, 21(2), 92-116. http://dx.doi.org/10.1108/MEDAR-07-2012-0023

Nieman, G., \& Nieuwenhuizen, C. (2009). Entrepreneurship: A South African Perspective. Van Schaik. 
Nyamwanza, T., Mavhiki, S., Mapetere, D., \& Nyamwanza, L. (2014). An analysis of SMEs' attitudes and practices toward tax compliance in Zimbabwe. SAGE Open, 4(3), 1-6.

Oakland, J. S. (2003). Total quality management: text with cases. Routledge.

Olawale, F., \& Garwe, D. (2010). Obstacles to the growth of new SMEs in South Africa: A principal component analysis approach. African journal of Business management, 4(5), 729-738.

Otero-Neira, C., Tapio Lindman, M., \& Fernández, M. J. (2009). Innovation and performance in SME furniture industries: An international comparative case study. Marketing Intelligence \& Planning, 27(2), 216-232. http://dx.doi.org/10.1108/02634500910944995

Otley, D. (2001). Accounting performance measurement: A review of its purposes and practices", International $\begin{array}{llll}\text { Journal of Business } \quad \text { Performance } & \text { Management, } & 3(2-4), & \text { 245-260. }\end{array}$ http://dx.doi.org/10.1504/IJBPM.2001.000102

Otley, D. (2007). Accounting performance measurement: a review of its purposes and practices. In Neely A. (Ed), Business Performance Measurement: Unifying theory and integrating practice (2nd ed), Cambridge: Cambridge University Press.

Padachi, K., Padachi, K., Lukea Bhiwajee, S., \& Lukea Bhiwajee, S. (2016). Barriers to employee training in small and medium sized enterprises: Insights and evidences from Mauritius. European Journal of Training and Development, 40(4), 232-247. http://dx.doi.org/10.1108/EJTD-02-2014-0018

Papadaki, E., \& Chami, B. (2002). Growth determinants of micro-businesses in Canada. Industry Canada, Small Business Policy Branch.

Parnell, J. A., Long, Z., \& Lester, D. (2015). Competitive strategy, capabilities and uncertainty in small and medium sized enterprises (SMEs) in China and the United States. Management Decision, 53(2), 402-431. http://dx.doi.org/10.1108/MD-04-2014-0222

Pekkola, S., Saunila, M., \& Rantanen, H. (2016). Performance measurement system implementation in a turbulent operating environment. International Journal of Productivity and Performance Management, 65(7), 947-958. http://dx.doi.org/10.1108/IJPPM-01-2015-0018

Quesada, H., \& Gazo, R. (2007). Methodology for determining key internal business processes based on critical success factors: A case study in furniture industry. Business Process Management Journal, 13(1), 5-20. http://dx.doi.org/10.1108/14637150710721104

Ramukumba, T. (2014). Overcoming SMEs Challenges through Critical Success Factors: A Case of SMEs in the Western Cape Province, South Africa. Economic and Business Review, 16(1): 19-39.

Ratnatunga, J., Gray, N., \& Balachandran, K. R. (2004). CEVITA ${ }^{\mathrm{TM}}$ : the valuation and reporting of strategic capabilities. Management Accounting Research, 15(1), 77-105. http://dx.doi.org/10.1016/j.mar.2003.12.005

Rockart, J. F. (1979). Chief executives define their own data needs. Harvard business review, 57(2), 81-93.

Rogoff, E. G., Lee, M. S., \& Suh, D. C. (2004). Who Done It?” Attributions by Entrepreneurs and Experts of the Factors that Cause and Impede Small Business Success. Journal of Small Business Management, 42(4), 364-376. http://dx.doi.org/10.1111/j.1540-627X.2004.00117.x

Saunila, M. (2016). Performance measurement approach for innovation capability in SMEs. International Journal $\begin{array}{llll}\text { of Productivity and Performance } & \text { Management, }\end{array}$ http://dx.doi.org/10.1108/IJPPM-08-2014-0123

Shi, M., \& Yu, W. (2013). Supply chain management and financial performance: literature review and future directions. International Journal of Operations \& Production Management, 33(10), 1283-1317. http://dx.doi.org/10.1108/IJOPM-03-2012-0112

Shirokova, G., Vega, G., \& Sokolova, L. (2013). Performance of Russian SMEs: Exploration, exploitation and strategic entrepreneurship. Critical perspectives on international business, 9(1/2), 173-203. http://dx.doi.org/10.1108/17422041311299941

Simpson, M., Padmore, J., \& Newman, N. (2012). Towards a new model of success and performance in SMEs. International Journal of Entrepreneurial Behavior \& Research, 18(3), 264-285. http://dx.doi.org/10.1108/13552551211227675

Simpson, M., Tuck, N., \& Bellamy, S. (2004). Small business success factors: the role of education and training", Education Training, 46(8/9), 481-491. http://dx.doi.org/10.1108/00400910410569605 
Staughton, R., \& Johnston, R. (2005). Operational performance gaps in business relationships. International Journal of Operations \& Production Management, 25(4), 320-332. http://dx.doi.org/10.1108/01443570510585525

Stokes, D., \& Wilson, N. (2006). Small Business Management and Entrepreneurship (5th ed.), London: Thomson.

Swee Lin Tan, C., X. Smyrnios, K. \& Xiong, L. (2014). What drives learning orientation in fast growth SMEs? International Journal of Entrepreneurial Behavior \& Research, 20(4), 324-350.

Taipale-Erävala, K., Heilmann, P., \& Lampela, H. (2014). Survival competence in Russian SMEs in a changing business environment. Journal of East-West Business, 20(1), 25-43. http://dx.doi.org/10.1108/IJEBR-02-2013-0032

Talke, K., Salomo, S., \& Kock, A. (2011). Top management team diversity and strategic innovation orientation: The relationship and consequences for innovativeness and performance. Journal of Product Innovation Management, 28(6), 819-832. 10.1111/j.1540-5885.2011.00851.x

Tarí, J. J., Molina, J. F., \& Castejon, J. L. (2007). "The relationship between quality management practices and their effects on quality outcomes. European Journal of Operational Research, 183(2), 483-501. http://dx.doi.org/10.1016/j.ejor.2006.10.016

Taschner, A. (2016). Improving SME logistics performance through benchmarking. Benchmarking: An International Journal, 23(7), 1780-1797. http://dx.doi.org/10.1108/BIJ-03-2015-0029

Taticchi, P., \& Balachandran, K. R. (2008). Forward performance measurement and management integrated frameworks. International Journal of Accounting \& Information Management, 16(2), 140-154. http://dx.doi.org/10.1108/18347640810913807

Temtime, Z. T., \& Solomon, G. H. (2002). Total quality management and the planning behavior of SMEs in developing economies. The TQM Magazine, 14(3), 181-191. http://dx.doi.org/10.1108/09544780210425900

Tracy, B. (2007). Eat that frog: 21 great ways to stop procrastinating and get more done in less time. Berrett-Koehler Publishers.

Tucker, M., \& Pitt, M. (2009). Customer performance measurement in facilities management: a strategic approach. International Journal of Productivity and Performance Management, 58(5), 407-422.

Turner, T. J., Bititci, U. S., \& Nudurupati, S. S. (2005). Implementation and impact of performance measures in two SMEs in Central Scotland. Production Planning \& Control, 16(2), 135-151. http://dx.doi.org/10.1108/17410400910965698

Uddin, M. R., \& Bose, T. K. (2013). Factors Affect the Success of SME in Bangladesh: Evidence from Khulna City. Journal of Management and Sustainability, 3(3), 166-173.

Utaumire., B, Mashiri, E., \& Mazhindu, K. (2013). Effectiveness of presumptive tax system in Zimbabwe: Case of ZIMRA Region one. Research Journal of Finance and Accounting, 4(7), 114-120.

Valaei, N., \& Rezaei, S. (2016). Does Web 2.0 utilisation lead to knowledge quality, improvisational creativity, compositional creativity, and innovation in small and medium-sized enterprises? A sense-making perspective. Technology Analysis \& Strategic Management, pp.1-14. http://dx.doi.org/10.1080/09537325.2016.1213806

Valaei, N., Rezaei, S., \& Ismail, W. K. W. (2017). Examining learning strategies, creativity, and innovation at SMEs using fuzzy set Qualitative Comparative Analysis and PLS path modeling. Journal of Business Research, 70, pp.224-233. http://dx.doi.org/10.1016/j.jbusres.2016.08.016

Vinten, G., Smith, M., \& Graves, C. (2005). Corporate turnaround and financial distress", Managerial Auditing Journal, 20(3), 304-320. http://dx.doi.org/10.1108/02686900510585627

Wach, D., Stephan, U., \& Gorgievski, M. (2016). More than money: Developing an integrative multi-factorial measure of entrepreneurial success. International Small Business Journal, 34(8), 1098-1121. https://doi.org/10.1177/0266242615608469

Wang, C. L. (2008). Entrepreneurial orientation, learning orientation, and firm performance. Entrepreneurship theory and practice, 32(4), 635-657. http://dx.doi.org/10.1111/j.1540-6520.2008.00246.x

Watson, K., Hogarth-Scott, S., \& Wilson, N. (1998). "Small business start-ups: success factors and support implications. International Journal of Entrepreneurial Behavior \& Research, 4(3), 217-238. http://dx.doi.org/10.1108/13552559810235510

Watts, T., \& McNair-Connolly, C. J. (2012). New performance measurement and management control systems. 
Journal of Applied Accounting Research, 13(3), 226-241. http://dx.doi.org/10.1108/09675421211281308

Wild, A. M. (2010). Learning the wrong lessons from history: Underestimating strategic change in business turnarounds. Business History, 52(4), 617-650. http://dx.doi.org/10.1080/00076791003753186

Wong, A., \& Sohal, A. (2002). Customers' perspectives on service quality and relationship quality in retail encounters. Managing Service Quality: An International Journal, 12(6), 424-433. http://dx.doi.org/10.1108/09604520210451902

Yazdanfar, D., \& Öhman, P. (2015). Firm-level determinants of job creation by SMEs: Swedish empirical evidence. Journal of Small Business and Enterprise Development, 22(4), 666-679. http://dx.doi.org/10.1108/JSBED-06-2013-0084

Yu, W. (2011). Operations strategy, business environment, operations resources and performance: an empirical study of retail firms in China, unpublished PHD thesis, Nottingham Business School.

Zerfass, A., \& Winkler, L., 2016. Corporate Communication in SMEs: Unveiling an Ignored Field of Practice. In Brønn, Romenti, Zerfass (Eds.), The Management Game of Communication (Advances in Public Relations and Communication Management, (Volume 1) Emerald Group Publishing Limited, pp. 265-286. http://dx.doi.org/10.1108/S2398-391420160000001014

\section{Copyrights}

Copyright for this article is retained by the author(s), with first publication rights granted to the journal.

This is an open-access article distributed under the terms and conditions of the Creative Commons Attribution license (http://creativecommons.org/licenses/by/4.0/). 